(c) American Dairy Science Association, 2004.

\title{
Effect of Molasses Supplementation on the Production of Lactating Dairy Cows Fed Diets Based on Alfalfa and Corn Silage*
}

\author{
G. A. Broderick and W. J. Radloff \\ Agricultural Research Service, USDA US Dairy Forage Research Center, \\ 1925 Linden Drive West, Madison, WI 53706
}

\section{ABSTRACT}

Adding sugar to the diet has been reported to improve production in dairy cows. In each of 2 trials, 48 lactating Holsteins (8 with ruminal cannulas) were fed covariate diets for $2 \mathrm{wk}$, blocked by days in milk into 12 groups of 4 , and then randomly assigned to diets based on alfalfa silage containing 4 levels of dried molasses (trial 1) or liquid molasses (trial 2). In both studies, production data were collected for $8 \mathrm{wk}$, ruminal samples were taken in wk 4 and 8 , and statistical models were used that included covariate means and block. In trial 1, experimental diets contained $18 \% \mathrm{CP}$ and $0,4,8$, or $12 \%$ dried molasses with $2.6,4.2,5.6$, or $7.2 \%$ total sugar. With increasing sugar, there was a linear increase in dry matter intake (DMI), and digestibility of dry matter (DM) and organic matter $(\mathrm{OM})$, but no effect on yield of milk or protein. This resulted in linear decreases in fat-corrected milk $(\mathrm{FCM}) / \mathrm{DMI}$ and milk N/N-intake. There was a linear decrease in urinary $\mathrm{N}$ with increasing sugar, and quadratic effects on milk fat content, yield of fat and FCM, and ruminal ammonia. Mean optimum from these quadratic responses was $4.8 \%$ total sugar in these diets. In trial 2, experimental diets contained $15.6 \%$ crude protein (CP) and $0,3,6$, or $9 \%$ liquid molasses with $2.6,4.9,7.4$, or $10.0 \%$ total sugar, respectively. Again, there were linear declines in FCM/DMI and milk N/ $\mathrm{N}$-intake with increasing sugar, but quadratic responses for DMI, yield of milk, protein, and SNF, digestibility of neutral detergent fiber and acid detergent fiber, milk urea, urinary excretion of purine derivatives, and ruminal ammonia. Mean optimum from all quadratic responses in this trial was $6.3 \%$ total sugar. An estimate of an overall optimum, based on yield of

Received February 9, 2004.

Accepted June 11, 2004.

Corresponding author: G. A. Broderick; e-mail: gbroderi@wisc.edu.

* Mention of any trademark or proprietary product in this paper does not constitute a guarantee or warranty of the product by the USDA or the Agricultural Research Service and does not imply its approval to the exclusion of other products that also may be suitable. fat and FCM (trial 1) and yield of milk, protein, and SNF (trial 2), was 5.0\% total sugar, equivalent to adding $2.4 \%$ sugar to the basal diets. Feeding more than $6 \%$ total sugar appeared to depress production.

(Key words: alfalfa silage, dried molasses, liquid molasses, total sugar)

Abbreviation key: HMSC = high moisture shelled corn, $\mathbf{P D}$ = purine derivatives, $\mathbf{S B M}=$ soybean meal.

\section{INTRODUCTION}

Diets based on alfalfa silage and similar hay-crop silages contain high levels of NPN and other sources of RDP (Muck, 1987; McDonald et al., 1991). When such diets are fed, ruminal carbohydrate and protein fermentation may be out of synchrony-that is, the rate of energy fermentation may be too slow to allow ruminal organisms to synthesize protein from the rapidly available RDP (Kim et al., 1999a). In these circumstances, increasing the rate of carbohydrate fermentation could result in more effective capture of RDP and improved supply of metabolizable protein to the dairy cow. There is in vitro evidence of enhanced net yield of ruminal microbial protein from the fermentation of sugars (Stokes et al., 1991). Sugars were more rapidly fermented in the rumen than starch (Chamberlain et al., 1993), suggesting that sugars could serve as effective supplements on alfalfa silage diets. Moreover, the Cornell Net Carbohydrate and Protein System (NRC, 1996) indicated that the organisms that ferment soluble sugars could contribute approximately $18 \%$ more microbial protein than the organisms that ferment starches in high moisture corn. Molasses, in dry or liquid form, is a practical source of dietary sugars for feeding to dairy cows (Hall, 2002). Therefore, the objective of these studies was to test the effects of replacing starch with sugar in lactating cows fed diets based on fermented feeds, principally alfalfa silage, corn silage, and high moisture shelled corn (HMSC). Dietary HMSC was replaced by incremental amounts of dried molasses in trial 1, and by liquid molasses in trial 2 . 
Table 1. Composition of forages.

\begin{tabular}{lllllr}
\hline & \multicolumn{2}{c}{ Trial 1 } & & \multicolumn{2}{c}{ Trial 2} \\
\cline { 2 - 3 } \cline { 6 - 7 } Component & $\begin{array}{l}\text { Alfalfa } \\
\text { silage }\end{array}$ & $\begin{array}{l}\text { Corn } \\
\text { silage }\end{array}$ & & $\begin{array}{l}\text { Alfalfa } \\
\text { silage }\end{array}$ & $\begin{array}{l}\text { Corn } \\
\text { silage }\end{array}$ \\
\hline DM, \% & 39.2 & 40.1 & & 47.7 & 31.5 \\
CP, \% of DM & 23.5 & 6.9 & & 21.3 & 7.9 \\
Ash, \% of DM & 10.5 & 3.8 & & 10.3 & 5.5 \\
NDF, \% of DM & 37.9 & 37.9 & & 41.3 & 38.9 \\
ADF, \% of DM & 28.6 & 20.6 & & 31.4 & 24.5 \\
pH & 4.7 & 4.0 & & 4.8 & 3.8 \\
NPN, \% of total N & 49.9 & 53.4 & & 49.4 & 45.4 \\
Ammonia-N, & 6.4 & 3.7 & & 7.4 & 10.8 \\
\% of total N & & & & & \\
ADIN, \% of total N & 4.4 & 1.5 & & 4.2 & 3.9 \\
\hline
\end{tabular}

\section{MATERIALS AND METHODS}

\section{Trial 1}

Forty multiparous Holstein cows ( 8 with ruminal cannulas) averaging parity 3.0 (SD 1.3), 653 (SD 52) $\mathrm{kg}$ BW, 128 (SD 75) DIM, and 41 (SD 5) kg of milk/d, and 8 primiparous Holstein cows averaging 561 (SD 40) $\mathrm{kg} \mathrm{BW}, 152$ (SD 69) DIM, and 38 (SD 3) kg of milk/ $\mathrm{d}$, were blocked into groups of 4 by DIM to give 10 multiparous blocks (2 of cows with ruminal cannulas) and 2 primiparous blocks in a trial of randomized complete block design. Care and handling of all experimental animals, including ruminal cannulation, was conducted under protocols approved by the University of Wisconsin Institutional Animal Care and Use Committee. Before starting the experimental phase of the trial, all cows were fed the same diet for a 2 -wk covariate period and production of milk and milk components was determined for use in statistical analysis. Cows within blocks of 4 were then randomly assigned to 1 of 4 diets and fed only that diet during the remaining 8 wk on study.

Forage was approximately $66 \%$ from alfalfa silage and $34 \%$ from corn silage in all diets. The alfalfa silage was harvested from the fourth cutting using a conventional mower conditioner, field wilted to about $40 \%$ $\mathrm{DM}$, chopped to a theoretical length of $2.9 \mathrm{~cm}$, and ensiled in a large bunker silo after inoculation with $100,000 \mathrm{cfu} / \mathrm{g}$ of wet silage (H/MF inoculant, Medipharm USA, Des Moines, IA) (Table 1). Corn silage was a brown midrib variety (F657, Cargill Hybrid Seeds, Minneapolis, MN) harvested at about one-half milk line, chopped to a theoretical length of $1.9 \mathrm{~cm}$ and field-

Table 2. Composition of diets.

\begin{tabular}{|c|c|c|c|c|c|c|c|c|c|}
\hline \multirow[b]{3}{*}{ Ingredient } & \multicolumn{5}{|c|}{ Trial 1} & \multicolumn{4}{|c|}{ Trial 2} \\
\hline & 0 & 0 & 4 & 8 & 12 & \multirow{2}{*}{${ }_{\text {Cov/cont }}{ }^{1}$} & \multirow{2}{*}{$\begin{array}{l}3 \\
1 \times\end{array}$} & \multirow{2}{*}{$\begin{array}{l}6 \\
2 \times\end{array}$} & \multirow{2}{*}{$\begin{array}{l}9 \\
3 \times\end{array}$} \\
\hline & Covariate & Control & $1 \times$ & $2 \times$ & $3 \times$ & & & & \\
\hline & \multicolumn{5}{|c|}{$\longrightarrow(\%$ of $\mathrm{DM}$} & & & & \\
\hline Alfalfa silage & 39.4 & 39.7 & 39.7 & 39.8 & 39.8 & 32.1 & 32.1 & 32.1 & 32.1 \\
\hline Corn silage & 21.8 & 20.6 & 20.6 & 20.6 & 20.7 & 19.7 & 19.7 & 19.7 & 19.7 \\
\hline High moisture shelled corn & 29.5 & 28.8 & 24.8 & 20.8 & 16.8 & 36.1 & 33.3 & 30.4 & 27.5 \\
\hline Fat supplement ${ }^{2}$ & 0.0 & 2.0 & 2.0 & 2.0 & 2.0 & 0.0 & 0.0 & 0.0 & 0.0 \\
\hline Solvent soybean meal & 3.9 & 7.8 & 7.8 & 7.8 & 7.8 & 6.7 & 6.7 & 6.7 & 6.7 \\
\hline Roasted soybeans & 4.4 & 0.0 & 0.0 & 0.0 & 0.0 & 4.2 & 4.2 & 4.2 & 4.2 \\
\hline Dried molasses ${ }^{3}$ & 0.0 & 0.0 & 3.9 & 7.9 & 11.8 & - & - & - & - \\
\hline Liquid molasses ${ }^{3}$ & - & - & - & - & - & 0.0 & 2.9 & 5.8 & 8.7 \\
\hline Sodium bicarbonate & 0.4 & 0.4 & 0.4 & 0.4 & 0.4 & 0.5 & 0.5 & 0.5 & 0.5 \\
\hline Salt & 0.3 & 0.3 & 0.3 & 0.3 & 0.3 & 0.3 & 0.3 & 0.3 & 0.3 \\
\hline Dicalcium phosphate & 0.2 & 0.2 & 0.2 & 0.2 & 0.2 & 0.2 & 0.2 & 0.2 & 0.2 \\
\hline Vitamin-mineral concentrate ${ }^{4}$ & 0.2 & 0.2 & 0.2 & 0.2 & 0.2 & 0.2 & 0.2 & 0.2 & 0.2 \\
\hline \multicolumn{10}{|l|}{ Chemical composition } \\
\hline $\mathrm{CP}$ & 18.1 & 18.1 & 17.9 & 17.9 & 18.1 & 15.5 & 15.7 & 15.5 & 15.7 \\
\hline Ash & 8.0 & 6.8 & 7.6 & 7.8 & 7.8 & 6.7 & 7.2 & 7.8 & 8.2 \\
\hline NDF & 30.5 & 28.2 & 29.1 & 29.2 & 29.3 & 25.9 & 26.0 & 26.5 & 24.5 \\
\hline $\mathrm{ADF}$ & 20.5 & 18.3 & 19.3 & 19.6 & 20.0 & 17.8 & 18.3 & 18.7 & 17.3 \\
\hline $\mathrm{NFC}$ & 39.6 & 42.8 & 41.4 & 40.7 & 41.2 & 48.1 & 47.4 & 46.5 & 47.9 \\
\hline Starch & 29.4 & 31.5 & 28.4 & 25.2 & 23.2 & 31.4 & 29.1 & 27.5 & 26.1 \\
\hline Total sugar & 2.4 & 2.6 & 4.2 & 5.6 & 7.2 & 2.6 & 4.9 & 7.4 & 10.0 \\
\hline Added sugar & 0.0 & 0.0 & 1.6 & 3.0 & 4.6 & 0.0 & 2.4 & 4.8 & 7.4 \\
\hline \multirow{2}{*}{\multicolumn{10}{|c|}{$\begin{array}{l}{ }^{1} \text { In trial 2, the same diet (Cov/cont) was used for both the covariate and control treatments. } \\
{ }^{2} \text { Fat supplement (Energy Booster 100) obtained from Milk Specialties, Dundee, IL. }\end{array}$}} \\
\hline & & & & & & & & & \\
\hline \multicolumn{10}{|c|}{$\begin{array}{l}{ }^{3} \text { Dried molasses (Plantation's Best) and liquid molasses obtained from Westway Trading Corp., New } \\
\text { Orleans, LA. }\end{array}$} \\
\hline${ }^{4}$ Provided per kilogram of $\mathrm{DN}$ & r & & & & $x_{1}$ & $\mathrm{mo} \cdot \mathrm{I} \cap \mathrm{g}$ & & & \\
\hline
\end{tabular}


processed with rolling (roller clearance of 1 to $3 \mathrm{~mm}$ ), then ensiled in a large upright silo without additives (Table 1). The covariate diet was formulated from these silages, HMSC, 48\% CP solvent-extracted soybean meal (SBM), roasted soybeans, plus minerals and vitamins (Table 2). The 4 experimental diets were similar except that some of the HMSC was replaced with dried molasses (Plantation's Best, Westway Trading Corp., New Orleans, LA) in stepwise increments from 0 to $11.8 \%$ of dietary DM (Table 2). This molasses product was made by drying cane molasses onto soybean mill feed (similar to soy hulls), and it contained approximately $22 \% \mathrm{ADF}$ and $42 \%$ total sugars as invert (Dave Caldwell, personal communication, 2003). Roasted soybeans were replaced by SBM plus a fat supplement (Energy Booster 100, Milk Specialties Co., Dundee, IL) in the experimental diets to reduce dietary RUP and make cows more responsive to changes in microbial protein supply (Table 2). When removed from the silo, HMSC was rolled to a geometric mean particle size of about $2 \mathrm{~mm}$ (Broderick et al., 2001). All diets were fed as TMR.

Cows were milked twice daily and individual milk yields were recorded at each milking. Milk samples were collected at 2 consecutive (p.m. and a.m.) milkings midway through wk 2 of the covariate period and midway through wk $2,4,6$, and 8 of the experimental phase, and analyzed for fat, protein, lactose, and SNF by infrared methods (AOAC, 1997) (Foss Milkoscan 4000, Foss North America, Eden Prairie, MN; AgSource, Verona, WI). Milk samples were deproteinized (Shahani and Sommer, 1951) and analyzed for MUN by an automated colorimetric assay (Broderick and Clayton, 1997), adapted to a flow-injection analyzer (Lachat Quick-Chem 8000 FIA; Zellweger Analytical, Milwaukee, WI). Concentrations and yields of fat, protein, lactose, and SNF, as well as MUN concentrations, were computed as the weighted means from p.m. and a.m. milk yields on each test day. Yields of 3.5\% FCM were also computed (Sklan et al., 1992). Efficiency of conversion of feed DM was calculated for each cow over the last 2 wk of each period by dividing mean FCM yield by mean DMI; similarly, efficiency of use of feed $\mathrm{N}$ was computed for each cow by dividing mean milk $\mathrm{N}$ output (total milk protein/6.38) by mean $\mathrm{N}$ intake. Body weights were measured on 3 consecutive days at the start and end of the 8-wk experimental phase to compute BW change.

All cows were injected with $500 \mathrm{mg}$ of bST (Posilac; Monsanto, St. Louis, MO) beginning on d 1 of the covariate period and at 14-d intervals throughout the trial. Cows were housed in tie stalls and had free access to water during the trial. The TMR were offered once daily at about $1000 \mathrm{~h}$; orts were collected and recorded once daily at about $0900 \mathrm{~h}$. The feeding rate was adjusted daily to yield orts of about $10 \%$ of intake. Weekly composites of the TMR, orts, alfalfa silage, corn silage, and HMSC were collected from daily samples of about $0.5 \mathrm{~kg}$ and stored at $-20^{\circ} \mathrm{C}$. Weekly samples of the roasted soybeans and SBM were stored at 21 to $24^{\circ} \mathrm{C}$. Proportions of each ration ingredient on an as-fed basis were adjusted weekly based on DM determined by drying weekly composites at $60^{\circ} \mathrm{C}(48 \mathrm{~h})$ for alfalfa silage, corn silage, and HMSC, and at $105^{\circ} \mathrm{C}$ (AOAC, 1980) for roasted soybeans, SBM, and dried molasses; Energy Booster, mineral, and vitamin supplements were assumed to have $100 \% \mathrm{DM}$. Intake of DM was calculated based on the $60^{\circ} \mathrm{C} \mathrm{DM}$ values for TMR and orts. After drying, major dietary ingredients and TMR were ground through a 1-mm screen (Wiley mill; Arthur H. Thomas, Philadelphia, PA) and then analyzed for DM at $105^{\circ} \mathrm{C}$, ash and $\mathrm{OM}$ (AOAC, 1980 ), total $\mathrm{N}$ by combustion assay (Leco 2000; Leco Instruments, Inc., St. Joseph, MI), and sequentially for NDF and ADF using heat stable amylase (Van Soest et al., 1991) and $\mathrm{Na}_{2} \mathrm{SO}_{3}$ (Hintz et al., 1995) during the NDF step. The TMR composites were analyzed for total fat (AOAC method 920.39, AOAC, 1997; Dairyland Laboratories, Arcadia, WI) to calculate NFC, and for soluble sugars using sucrose as the standard, and for starch (Hall et al., 1999; T. K. M. Webster, West Virginia Univ., Morgantown). Composition data in Table 2 were from analysis of TMR composites. At the end of the trial, weekly composites of alfalfa silage and corn silage were thawed, water extracts were prepared, deproteinized, and then analyzed for NPN (Muck, 1987) using a combustion $\mathrm{N}$ assay (Mitsubishi TN-05 Nitrogen Analyzer; Mitsubishi Chemical Corp., Tokyo, Japan).

At the end of wk 4 and 8 of the experimental phase, 2 spot fecal and urine samples were collected from all cows at about 6 and $18 \mathrm{~h}$ after feeding. Fecal samples were dried in a forced draft oven $\left(60^{\circ} \mathrm{C} ; 72 \mathrm{~h}\right)$, and then ground through a 1-mm screen (Wiley mill, Arthur H. Thomas). Equal DM from each fecal subsample was mixed to obtain one composite for each cow at both sampling times (24 samples per dietary treatment). Each fecal composite was analyzed as described earlier for DM, ash, OM, NDF, ADF, and total N. Fecal composites and the wk-4 and -8 TMR samples were analyzed for indigestible ADF (i.e., the ADF remaining after $12 \mathrm{~d}$ of in situ ruminal incubations; Huhtanen et al., 1994). Indigestible ADF was used as an internal marker to estimate relative differences due to treatment in apparent nutrient digestibility and fecal output (Cochran et al., 1986). Fresh urine samples were acidified by diluting 1 volume of urine with 4 volumes of $0.072 \mathrm{~N} \mathrm{H}_{2} \mathrm{SO}_{4}$ and storing at $-20^{\circ} \mathrm{C}$ until analyzed. At the end of the trial, all urine samples were thawed 
at room temperature, and filtered through Whatman no. 1 filter paper. Filtrates were analyzed for creatinine using a picric acid assay (Oser, 1965) adapted to the flow-injection analyzer (Lachat Quick-Chem), for total N (Mitsubishi Nitrogen Analyzer), for allantoin using the method of Vogels and van der Grift (1970) adapted to a 96-well plate reader, for uric acid using a commercial kit (No. 683-100P, Sigma Chem. Co., St. Louis, MO), and for urea with the colorimetric method used for MUN. Daily urine volume and excretion of urea $\mathrm{N}$, total $\mathrm{N}$, and purine derivatives (PD; allantoin plus uric acid) were estimated from mean urinary concentrations assuming a creatinine excretion rate of 29 $\mathrm{mg} / \mathrm{kg}$ of BW (Valadares et al., 1999).

About 100 to $200 \mathrm{~mL}$ of digesta was collected from the ventral rumen of cannulated cows at 0 (just before feeding), 1, 2, 4, 6, 8, and $12 \mathrm{~h}$ after the feeding on the last days of wh 4 and 8 of the experimental phase, and strained through 2 layers of cheesecloth; $\mathrm{pH}$ was measured immediately. One sample from each cow was preserved at each time by adding $0.2 \mathrm{~mL}$ of $50 \%$ (vol/ vol) $\mathrm{H}_{2} \mathrm{SO}_{4}$ to $10 \mathrm{~mL}$ of strained ruminal fluid and storing samples at $-20^{\circ} \mathrm{C}$. Just prior to analysis, samples were thawed and centrifuged $(15,300 \times g$ for 20 min at $4^{\circ} \mathrm{C}$ ). Flow-injection analyses (Lachat QuickChem) were applied to supernatants to determine ammonia using a phenol-hypochlorite method (Lachat Method 18-107-06-1-A), and total AA using a fluorimetric procedure based on reaction with $o$-phthalaldehyde (Roth, 1971). Leucine was the standard in the $o$ phthalaldehyde assay, and total AA are reported in leucine equivalents. Samples were thawed and centrifuged $\left(28,000 \times g\right.$ for $30 \mathrm{~min}$ at $\left.4^{\circ} \mathrm{C}\right)$ for determination of individual and total ruminal VFA using a modification of the GLC method for FFA described in Supelco Bulletin 855B (Supelco Inc., Supelco Park, Bellefonte, PA) with flame-ionization detection. Standards or supernatants $(1 \mu \mathrm{L})$ were injected onto a ZB-FFAP capillary column $(30 \mathrm{~m} \times 0.53 \mathrm{~mm} \times 1.0 \mu \mathrm{m}$; no. $7 \mathrm{HK}$ G009-22; Phenomenex Inc., Torrance, CA) with helium carrier gas at $100 \mathrm{KPa}$ and a flow rate of $20 \mathrm{~mL} / \mathrm{min}$. Column oven temperature was $100^{\circ} \mathrm{C}$ at injection; after $2 \mathrm{~min}$, temperature was increased to $130^{\circ} \mathrm{C}$ at a rate of $10^{\circ} \mathrm{C} / \mathrm{min}$. Injector and detector temperatures were 230 and $250^{\circ} \mathrm{C}$, respectively. Response areas from standards were used to compute VFA concentrations in ruminal samples. The method did not resolve isovalerate and 2-methylbutyrate. Individual VFA are reported in concentration units rather than as molar proportions.

\section{Trial 2}

The same randomized complete block design also was used in this study. Forty-eight multiparous Hol- stein cows (4 with ruminal cannulas), averaging parity 2.9 (SD 1.1), 622 (SD 76) kg BW, 85 (SD 51) DIM, and 44 (SD 6) $\mathrm{kg}$ of milk/d, were blocked into groups of 4 by DIM to give 12 blocks (one block with ruminal cannulas). One additional block of late-lactation, ruminally cannulated cows of parity 2 and averaging 625 (SD 58) kg BW, 320 (SD 53) DIM, and 24 (SD 6) kg of milk/d was included for ruminal sampling but was not used for production data. As in trial 1, cows were fed a covariate TMR for 2 wk before being randomly assigned to 1 of 4 TMR with different sugar contents for the 8-wk experimental phase. Diets fed in this trial differed in that forage was $62 \%$ from alfalfa silage and $38 \%$ from corn silage in all diets and the covariate and control diets (no added molasses) were identical (Table 2 ). Alfalfa silage was harvested from second cutting using a conventional mower conditioner, field wilted to about $48 \% \mathrm{DM}$, chopped to a theoretical length of $2.9 \mathrm{~cm}$, and ensiled in a large tower silo using the same inoculant as trial 1 (Table 1). Corn silage was the same variety, harvested, and processed as described in trial 1 , except that it was ensiled in a large bunker silo (Table 1). Diets were formulated from alfalfa silage, corn silage, HMSC, SBM, roasted soybeans, plus minerals and vitamins (Table 2). The experimental diets were the same except that some of the HMSC was replaced with liquid molasses (WesBlend 66, Westway Trading Corp., New Orleans, LA) in stepwise increments from 0 (control) to $8.7 \%$ of dietary DM (Table 2 ). This was cane molasses containing $79.5 \%$ total sugars as invert and 74\% DM (Dave Caldwell, personal communication, 2003) that was diluted with water to about $67 \%$ DM. It was dispensed into the TMR during mixing using a pipe manifold with 10 spouts to distribute the molasses evenly into the experimental diets. Proportions of dietary DM from each ration ingredient were adjusted weekly as described for trial 1 . All other aspects of the trial, including milk sampling, feeding protocols, and sampling and analyses of feed, feces, urine, and ruminal contents were conducted as described for trial 1, except that milk analysis was conducted using a different instrument (Foss Milkoscan FT-6000, Foss North America, Eden Prairie, MN; AgSource, Verona, WI), and ruminal digesta samples were collected at $0,1,2,4,6,9,12$, and $18 \mathrm{~h}$ after feeding on the last days of wk 4 and 8 of the experimental phase.

\section{Statistical Analysis}

A single mean value was calculated for each cow over the 8-wk experimental phase of both trials for the production traits listed in Tables 3 and 4. Statistical analyses of all these data, except for BW gain, MUN 
Table 3. Effect of replacing high moisture shelled corn in the diet with dried molasses on production, nutrient digestibility, and excretion (trial 1).

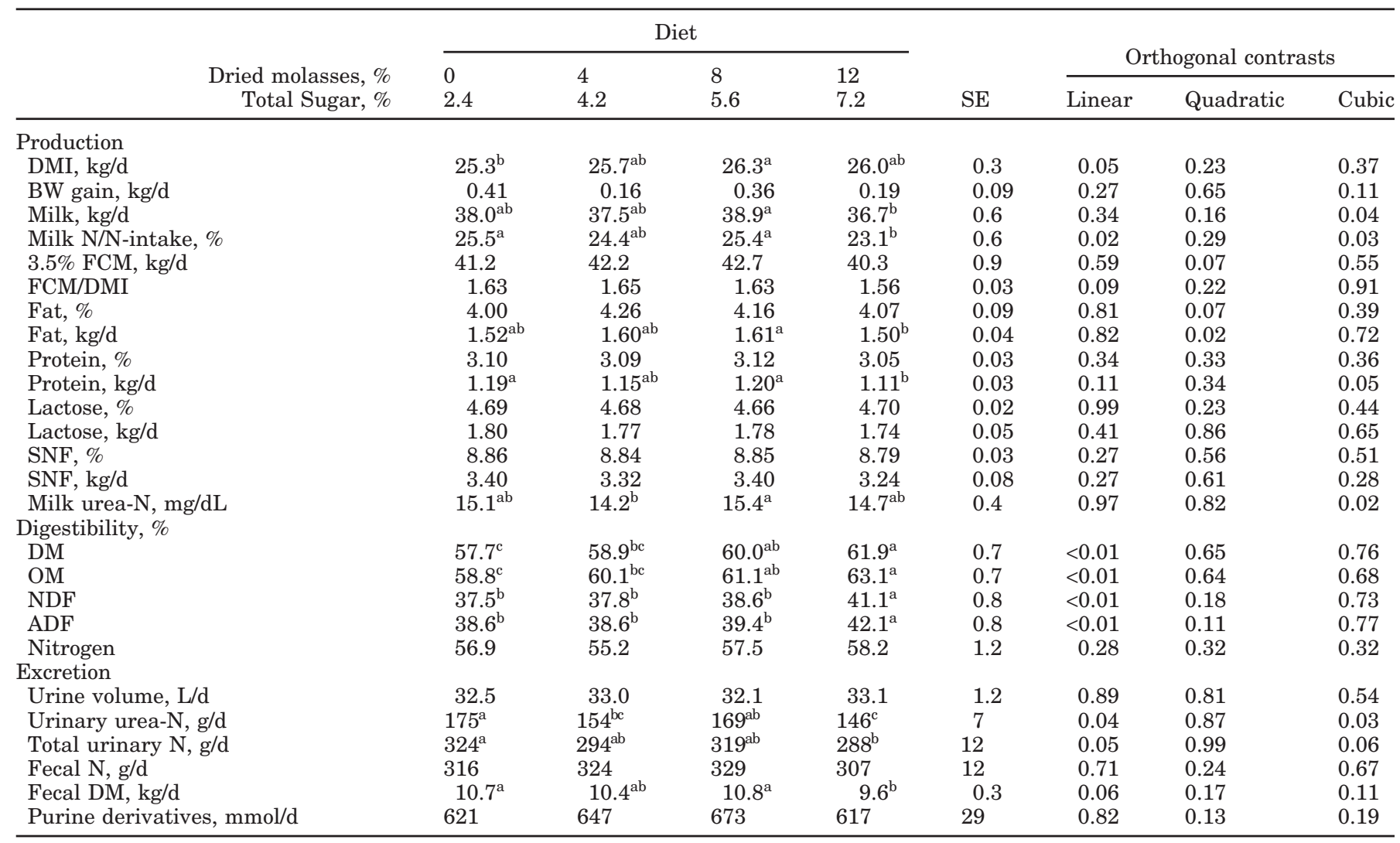

${ }^{\mathrm{a}, \mathrm{b}, \mathrm{c}}$ Least square means within the same row without a common superscript $\operatorname{differ}(P<0.05)$.

concentration, apparent digestibilities, and excretion traits, were done using the GLM procedure of SAS (1999) with a model that included the covariate mean for each cow plus block and dietary treatment. The same approach was used for BW gain, MUN, apparent digestibilities, and excretion traits listed in Table 3 and 4, except the model did not contain a covariate. Orthogonal contrasts were used to test for linear, quadratic, and cubic effects of adding each molasses source to the diet. Significance in each trial was declared at $P \leq 0.10$ and separation of least square means was conducted at $\alpha=0.05$ using PDIFF in the LSMEANS statement. A single time-weighted concentration mean for $\mathrm{H}^{+}$(Murphy, 1982), total VFA, and individual VFA was computed for each cow for each of the ruminal sampling weeks in both trials; mean $\mathrm{H}+$ concentrations were converted back to $\mathrm{pH}$ values. This approach yielded an estimate of the area under the time-concentration curve for each ruminal metabolite. Statistical analyses of these means were done using the GLM procedure of SAS (1999) with a model that included diet, block, sample week, and week $\times$ diet interaction. No week $\times$ diet interaction was significant $(P \geq 0.46$, trial 1; $P \geq 0.22$, trial 2). Orthogonal contrasts were used to test for significance of linear, quadratic, and cubic effects of adding each molasses source to the diet. Significance was declared at $P \leq 0.10$ and separation of least square means was conducted at $\alpha=0.05$ using PDIFF in the LSMEANS statement.

The significance of quadratic effects of molasses addition was at least $P<0.10$ for a number of traits (yield of 3.5\% FCM and fat, milk fat content, ruminal ammonia, trial 1; DMI, yield of milk, protein, and SNF, milk content of protein, SNF, and MUN, apparent digestibility of NDF and ADF, PD excretion, and ruminal ammonia, trial 2). When this occurred, the analytically determined concentrations of total sugar in the diets (Table 2) were used with the GLM procedure of SAS (1999) in a regression model that included block, sugar, and sugar $\times$ sugar to quantify the intercept and the coefficients for the linear and squared terms in the quadratic regression model. These equations were solved for the optimal concentration of dietary sugarthe point of maximal production and digestibility or minimal MUN and ruminal ammonia concentration. 
Table 4. Effect of replacing high moisture shelled corn in the diet with liquid molasses on production, nutrient digestibility, and excretion (trial 2).

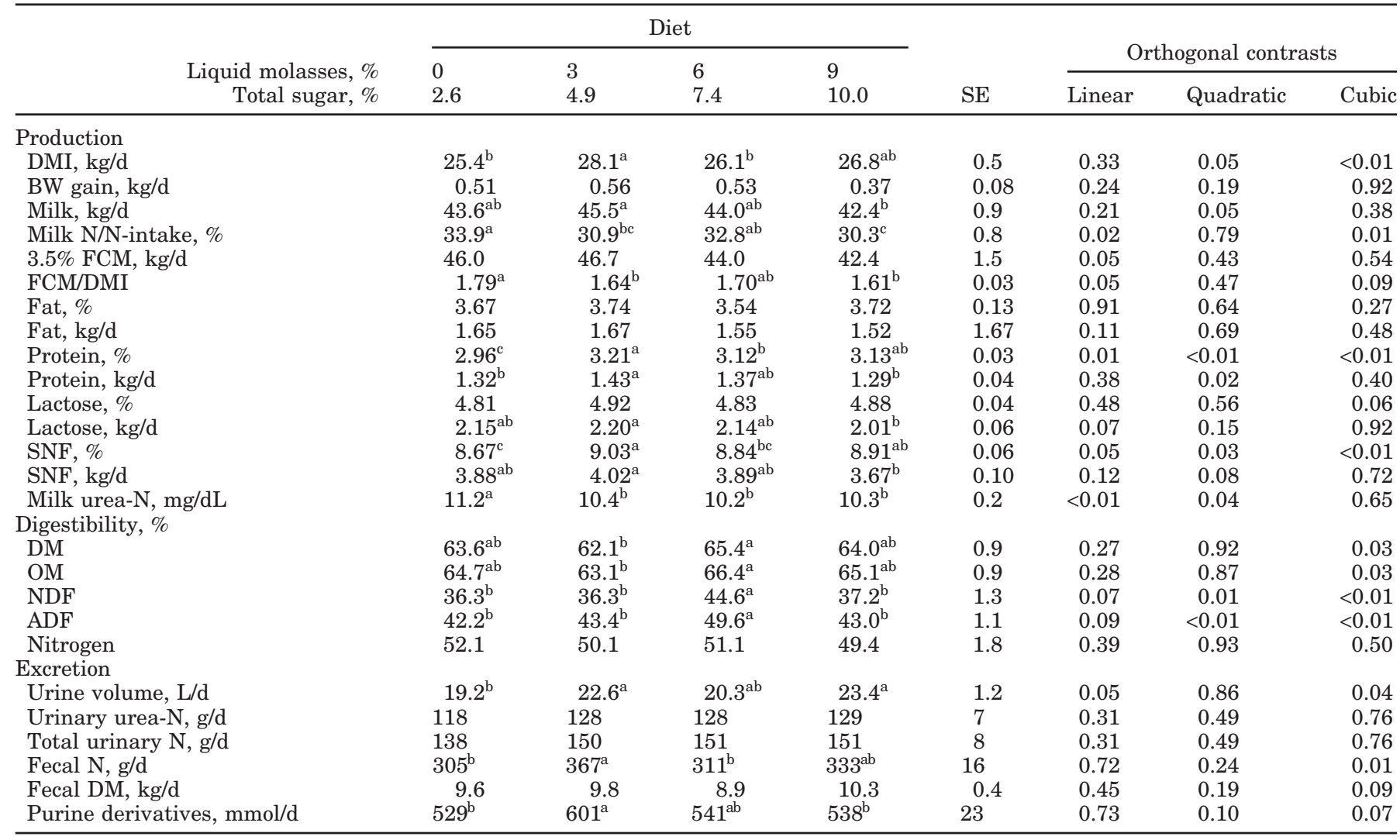

${ }^{\mathrm{a}, \mathrm{b}, \mathrm{c}}$ Least square means within the same row without a common superscript differ $(P<0.05)$.

\section{RESULTS AND DISCUSSION}

\section{Trial 1}

The alfalfa and corn silages fed in this study both contained less than $40 \% \mathrm{NDF}$, and had very low levels of ammonia-N and ADIN, indicating that they were of high quality and resulted from excellent fermentations in the silo (Table 1). However, the alfalfa silage contained more total $\mathrm{N}$ than normal, averaging $23.5 \% \mathrm{CP}$ over the course of the study. Initial samples of alfalfa silage had only $21 \% \mathrm{CP}$; thus, the 4 experimental diets averaged $18.0 \% \mathrm{CP}$ (Table 2) rather than $17 \% \mathrm{CP}$ for which they were originally formulated. The alfalfa (Broderick et al., 2001) and corn silages (McDonald et al., 1991) contained normal proportions of NPN, and forage NPN accounted for $30 \%$ of total dietary CP. High levels of NPN depress use of forage CP (Nagel and Broderick, 1992). These high levels of CP and NPN indicated that possible responses in microbial growth from supplemental sugar would not have been restricted by RDP supply in this trial. Nonstructural carbohydrate analysis of TMR composites indicated that stepwise replacement of HMSC (in 4\% incre- ments) with 0 to $12 \%$ dried molasses increased dietary sugars up to $4.8 \%$ of dietary DM. However, there was a $3.2 \%$ decrease in total nonstructural carbohydrates over this range due to starch declining more than total sugars increased (Table 2). This was because the dried molasses, which averaged $27.3 \%$ NDF over the study, had been produced by drying liquid molasses on a fibrous carrier, soybean mill feed (Dave Caldwell, personal communication, 2003). Soybean mill feed has fiber composition similar to soy hulls (www.ingredients101.com/soybeanh.htm). This means that results were confounded by a small stepwise increase in fiber with each increment of dietary sugar.

Despite this confounding effect, there was a linear increase in DMI, and quadratic responses in milk fat content and yield and FCM yield with increasing dietary sugar (Table 3). Elevation of feed intake with increasing dietary sugar has been observed in dairy cattle (Sutton et al., 2001). This effect may be mediated partly through improved palatability. Harvesting forages in late afternoon, just after maximal photosynthetic activity, increased total sugar and starch contents (Owens et al., 1999). Dry matter intake was in- 
creased in goats, sheep, and cattle when they were fed fescue hay (Fisher et al., 1999) or alfalfa hay (Fisher et al., 2002) harvested late in the day vs. hay harvested in early morning. Increased milk fat secretion also has been reported with the feeding of molasses to lactating cows (Morales et al., 1989; Murphy, 1999). This increased fat secretion has been attributed to increased butyrate production in the rumen (Khalili and Huhtanen, 1991). However, increased sugar intake (as dried molasses) did not alter ruminal concentrations of total VFA, acetate, butyrate, or any other individual VFA in the present trial (Table 5). Concentrations of VFA represent a balance between production and disappearance, and important differences in production rates may not be apparent from concentrations alone (Leng, 1970; Dijkstra et al., 1993). We also observed improved feed intake and fat yield but no effects on ruminal butyrate when replacing dietary cornstarch with sucrose in another trial (Broderick et al., 2000). Although not affected by diet, ruminal $\mathrm{pH}$ was quite low. This may have been because $\mathrm{pH}$ was measured in this trial for only the first $12 \mathrm{~h}$ after feeding on this once a day feeding regimen. Ruminal $\mathrm{pH}$ averaged 5.9 and 6.2 from, respectively, 0 to $12 \mathrm{~h}$ and 12 to $24 \mathrm{~h}$ after feeding in an earlier trial when cows were fed once a day (Ekinci, 1995).

Linear decreases were observed in apparent DM efficiency (FCM yield/DMI) and N efficiency (milk N/Nintake) with increasing dietary sugar. This occurred because of the linear increase in DMI that was unaccompanied by an increase in FCM yield. Milk and protein yield, as well as apparent $\mathrm{N}$ efficiency, showed significant cubic effects. The pattern of differences was the same for all 3 of these traits: There was no difference among the means observed for 0 to $8 \%$ dried molasses (2.4 to $5.6 \%$ total sugar), but the response observed at the highest level of supplementation was significantly reduced. This pattern indicated that production was in fact depressed at the highest level of added sugar. Huhtanen (1987) found that $1 \mathrm{~kg} / \mathrm{d}$ of molasses DM increased milk and protein yield, respectively, from 23.3 and $0.72 \mathrm{~kg} / \mathrm{d}$ to 24.0 and $0.76 \mathrm{~kg} / \mathrm{d}$ when fed in supplement of $9 \mathrm{~kg} / \mathrm{d}$ of grass silage and $6 \mathrm{~kg} / \mathrm{d}$ of other concentrates. However, feeding $2 \mathrm{~kg} / \mathrm{d}$ of molasses DM significantly reduced yield of milk, fat, and protein compared with the control diet. Based on the total sugar assays conducted in this trial, intakes were equivalent to approximately $0.5,1.0$, and $1.5 \mathrm{~kg} /$ $\mathrm{d}$ of molasses DM on the diets containing 3.9, 7.9, and $11.8 \%$ dried molasses, respectively.

Adding sugar to the diet resulted in linear increases in apparent $\mathrm{DM}$ and $\mathrm{OM}$ digestibility and a linear decrease in fecal DM output estimated using indigestible ADF as the marker. Previously, we found that this marker yielded underestimates in extent of digestion of 5 percentage units (DM, OM, and CP) and 9 percentage units (NDF and ADF) relative to the external marker $\mathrm{Yb}$; however, indigestible $\mathrm{ADF}$ and $\mathrm{Yb}$ were equally reliable at detecting differences in apparent digestibility of equal magnitude for $\mathrm{CP}, \mathrm{NDF}$, and $\mathrm{ADF}$ in diets containing control or macerated hay (Broderick et al., 1999). These results suggested that, despite the reduction in dietary nonstructural carbohydrates, energy availability was improved. Huhtanen (1988) also found improved OM digestibility when molasses DM replaced barley or beet pulp in cattle diets based on grass silage. Surprisingly, there were linear increases in NDF and ADF apparent digestibility with the feeding of increasing amounts of dried molasses. Most of the dietary fiber in the control diet (with 28.2\% NDF) came from alfalfa and corn silages. Although analysis of TMR composites collected during the trial indicated that dietary NDF increased by only $1.1 \%$ over the range of these diets (Table 2), a net increase of $2.2 \% \mathrm{NDF}$ was expected because dried molasses (with 28\% NDF) replaced $11.8 \%$ of dietary DM from HMSC (with 10\% NDF). Hussein et al. (1995) reported that extents of 24-h in situ digestion of NDF in alfalfa hay, corn silage, and soy hulls were, respectively, 26, 20 , and $32 \%$. Thus, the apparent improvement may have occurred partly because of greater intake of more digestible fiber with elevated levels of dried molasses in the diet.

Increased sugar intake was accompanied by some evidence for improved $\mathrm{N}$ use (Table 3). Levels of MUN were numerically lowest on $4 \%$ dried molasses (the diet containing $4.2 \%$ total sugar), and there were linear declines in urinary excretion of urea $\mathrm{N}$ and total $\mathrm{N}$ estimated from spot sampling of urine. Moreover, ruminal ammonia was lowest on the diet with $4 \%$ dried molasses (Table 5), and showed a quadratic response $(P=0.08)$ with a minimum predicted at $4.8 \%$ total sugar (Table 6). The quadratic effects $(P \leq 0.07$; Table 3) noted earlier for FCM yield, fat yield, and milk fat content, correspond to maxima at 4.7, 4.8, and 5.0\% total sugar in the diet (Table 6).

It was anticipated that sugar supplementation could have been beneficial through stimulation of microbial protein formation from the large amounts of RDP on these diets; thus, yield of milk and particularly protein should have been most affected by sugar feeding. Huhtanen (1988) observed increased flow of microbial CP to the small intestine and higher efficiency of microbial CP synthesis when molasses was supplemented to cattle fed grass silage. Diets fed in this trial were $1 \%$ greater than the target of $17 \% \mathrm{CP}$ and computations made using the NRC (2001) rationing system indicated that the experimental diets on average supplied suffi- 
Table 5. Effect of replacing high moisture shelled corn in the diet with dried molasses (trial 1) or liquid molasses (trial 2) on $\mathrm{pH}$ and concentration of metabolites in the rumen.

\begin{tabular}{|c|c|c|c|c|c|c|c|c|}
\hline \multirow{3}{*}{$\begin{array}{r}\text { Dried molasses, } \% \\
\text { Total sugar, \% }\end{array}$} & \multicolumn{4}{|c|}{ Diet } & \multirow[b]{3}{*}{$\mathrm{SE}$} & \multirow{2}{*}{\multicolumn{3}{|c|}{ Orthogonal contrasts }} \\
\hline & 0 & & 8 & 12 & & & & \\
\hline & 2.4 & 4.2 & 5.6 & 7.2 & & Linear & Quadratic & Cubic \\
\hline \multicolumn{9}{|l|}{ Trial 1} \\
\hline $\mathrm{pH}$ & 5.63 & 5.80 & 5.66 & 5.82 & 0.09 & 0.29 & 0.92 & 0.16 \\
\hline Ammonia, mg/dL & $16.5^{\mathrm{a}}$ & $13.6^{\mathrm{b}}$ & $15.7^{\mathrm{ab}}$ & $16.1^{\mathrm{a}}$ & 0.8 & 0.79 & 0.08 & 0.11 \\
\hline Total AA, mM & 1.83 & 1.19 & 2.23 & 2.16 & 0.44 & 0.33 & 0.54 & 0.20 \\
\hline Total VFA, mM & 134.4 & 131.1 & 138.2 & 133.5 & 4.3 & 0.82 & 0.88 & 0.29 \\
\hline Acetate, $\mathrm{m} M$ & 83.0 & 82.9 & 85.2 & 85.2 & 2.4 & 0.43 & 0.97 & 0.66 \\
\hline Propionate, $\mathrm{m} M$ & 29.9 & 27.5 & 30.4 & 26.7 & 2.2 & 0.51 & 0.76 & 0.26 \\
\hline Acetate:propionate ratio & 2.86 & 3.08 & 2.85 & 3.22 & 0.18 & 0.32 & 0.69 & 0.24 \\
\hline Butyrate, $\mathrm{m} M$ & 15.6 & 14.9 & 16.7 & 16.0 & 0.6 & 0.31 & 0.97 & 0.11 \\
\hline Branched-chain VFA, ${ }^{1} \mathrm{~m} M$ & 3.44 & 3.75 & 3.46 & 3.41 & 0.15 & 0.59 & 0.27 & 0.24 \\
\hline \multirow[t]{2}{*}{ Valerate, $\mathrm{m} M$} & 2.44 & 2.10 & 2.45 & 2.25 & 0.12 & 0.71 & 0.60 & 0.16 \\
\hline & \multicolumn{4}{|c|}{ Diet } & & \multirow{2}{*}{\multicolumn{3}{|c|}{ Orthogonal contrasts }} \\
\hline Dried molasses, \% & 0 & 3 & 6 & 9 & & & & \\
\hline Total sugar, \% & 2.6 & 4.9 & 7.4 & 10.0 & $\mathrm{SE}$ & Linear & Quadratic & Cubic \\
\hline \multicolumn{9}{|l|}{ Trial 2} \\
\hline $\mathrm{pH}$ & 6.07 & 5.90 & 6.02 & 6.06 & 0.11 & 0.89 & 0.38 & 0.50 \\
\hline Ammonia, mg/dL & $7.58^{\mathrm{ab}}$ & $7.05^{\mathrm{b}}$ & $6.50^{\mathrm{b}}$ & $9.30^{\mathrm{a}}$ & 0.76 & 0.22 & 0.06 & 0.35 \\
\hline Total AA, mM & 5.22 & 4.76 & 4.23 & 4.79 & 0.32 & 0.25 & 0.16 & 0.46 \\
\hline Total VFA, mM & 112.1 & 117.9 & 116.3 & 117.0 & 4.1 & 0.50 & 0.55 & 0.61 \\
\hline Acetate, $\mathrm{m} M$ & 68.4 & 70.4 & 69.2 & 73.2 & 1.5 & 0.09 & 0.52 & 0.26 \\
\hline Propionate, $\mathrm{m} M$ & 25.1 & 28.4 & 26.7 & 23.6 & 2.7 & 0.64 & 0.28 & 0.78 \\
\hline Acetate:propionate ratio & 2.81 & 2.54 & 2.74 & 3.24 & 0.30 & 0.30 & 0.24 & 0.90 \\
\hline Butyrate, $\mathrm{m} M$ & 14.0 & 14.4 & 14.2 & 15.6 & 0.9 & 0.29 & 0.60 & 0.58 \\
\hline Branched-chain VFA, ${ }^{1} \mathrm{~m} M$ & $2.76^{\mathrm{b}}$ & $2.76^{\mathrm{b}}$ & $3.25^{\mathrm{a}}$ & $2.74^{\mathrm{b}}$ & 0.14 & 0.50 & 0.11 & 0.05 \\
\hline Valerate, $\mathrm{m} M$ & 1.84 & 1.97 & 2.89 & 1.82 & 0.35 & 0.60 & 0.13 & 0.12 \\
\hline
\end{tabular}

${ }^{\mathrm{a}, \mathrm{b}}$ Least square means within the same row without a common superscript differ $(P<0.05)$.

${ }^{1}$ Branched-chain VFA computed as the sum of isobutyrate and isovalerate plus 2-methylbutyrate.

cient metabolizable protein to support only $36 \mathrm{~kg} / \mathrm{d}$ of milk. Moreover, these diets averaged $29 \% \mathrm{NDF}$ and $42 \%$ NFC (Table 2) and were estimated to supply sufficient $\mathrm{NE}_{\mathrm{L}}$ to support $41 \mathrm{~kg} / \mathrm{d}$ of milk yield (NRC, 2001). However, the indicators suggesting improved $\mathrm{N}$ use were not accompanied by a general improvement in milk production. Although satisfactory for assessing relative effects of diet (Valadares et al., 1999), urinary and fecal $\mathrm{N}$ excretion estimated using internal markers and spot sampling likely were less accurate (and less reliable) than our direct measurements of milk $\mathrm{N}$ secretion. Indeed, mean $\mathrm{N}$ intake in this trial was 744 $\mathrm{g} / \mathrm{d}$ and mean $\mathrm{N}$ output as milk $\mathrm{N}$ plus estimated fecal $\mathrm{N}$ and urinary $\mathrm{N}$ was $807 \mathrm{~g} / \mathrm{d}$, indicating that $64 \mathrm{~g} / \mathrm{d}$ of $\mathrm{N}$ was unaccounted for. Overall, the cows began the present study at a mean 132 DIM and may have been too far down the lactation curve to be responsive to additional metabolizable protein resulting from increased microbial growth in the rumen. A number of other researchers have failed to obtain positive effects of sugar supplementation on ruminal $\mathrm{N}$ use. Hall and Herejk (2001) observed greater maximum yield of microbial protein from starch than sucrose addition to ruminal in vitro incubations. Sannes et al. (2002) re- ported that sucrose supplementation did change total PD excretion but microbial protein synthesis, which was computed from PD excretion and purine: $N$ ratio of isolated ruminal bacterial, appeared to be reduced with sucrose feeding.

\section{Trial 2}

The alfalfa silage contained less CP and more NDF than that used in trial 1; the corn silage, although similar in $\mathrm{CP}$ and NDF, was lower in ammonia-N and ADIN but higher in NPN than that fed in trial 1 (Table 1). Forage NPN accounted for $26 \%$ of dietary CP in this study. Nevertheless, both silages were in the range of normal composition (NRC, 2001) and of good quality. Diets fed in this trial were formulated to contain $16 \%$ $\mathrm{CP}$ and averaged $15.6 \% \mathrm{CP}$ over the course of the study (Table 2); this was $2.4 \%$ lower in CP than diets fed in trial 1. Estimated metabolizable protein allowable milk was $38 \mathrm{~kg} / \mathrm{d}$ (NRC, 2001) on the average intake of the experimental diets fed in this study. Analysis of TMR composites collected during the trial indicated that total nonstructural carbohydrates (starch plus total sugar) were slightly higher and, as expected, did 
Table 6. Optimum total dietary sugar concentration estimated for performance traits with significant quadratic effects $(P<0.10)$.

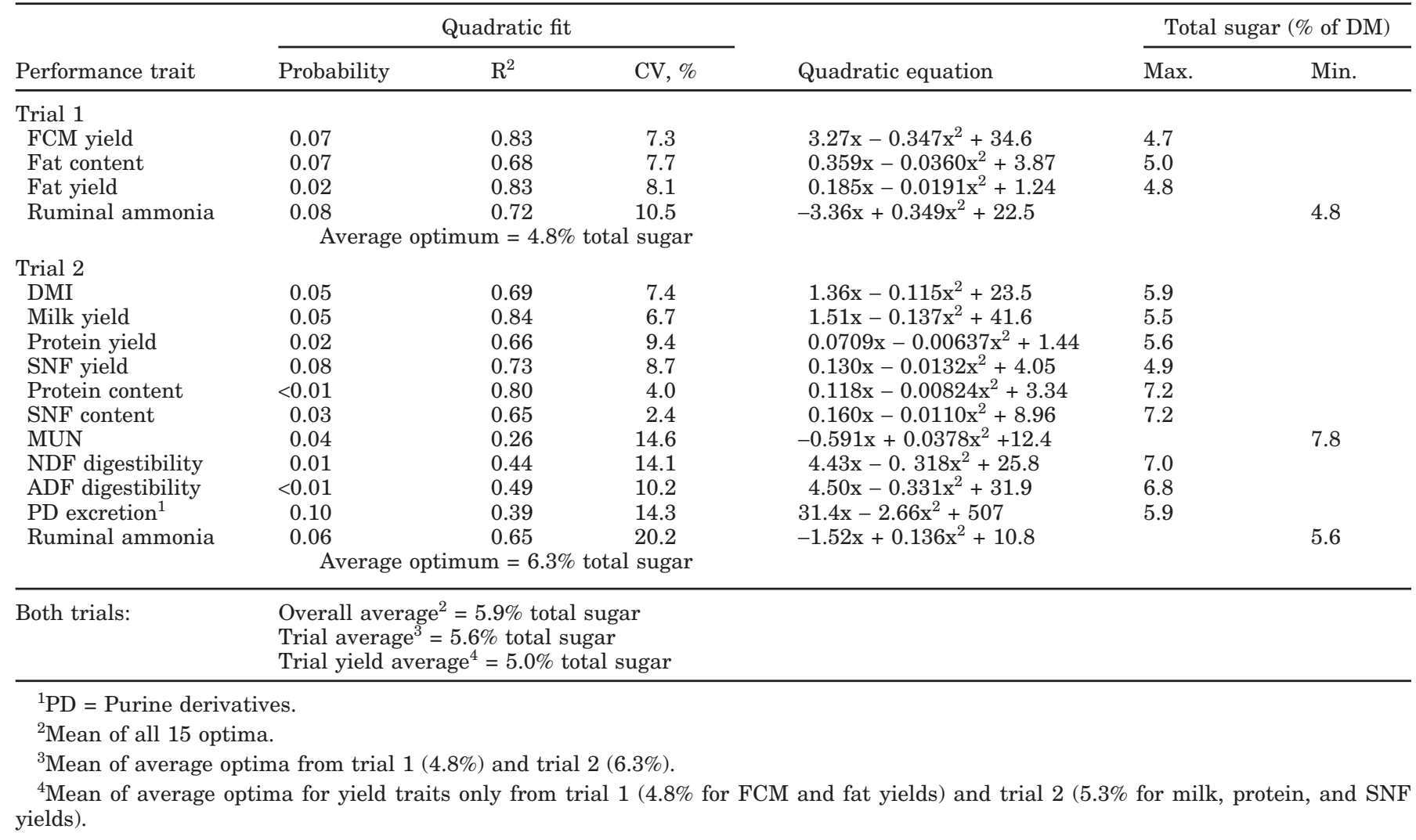

not alter with increasing supplementation of liquid molasses (Table 2). Moreover, NDF was about $3 \%$ lower and NFC about 6\% higher than in trial 1, and $\mathrm{NE}_{\mathrm{L}}$ allowable milk was computed at $43 \mathrm{~kg} / \mathrm{d}$ (NRC, 2001). Actual milk yield in this trial averaged $44 \mathrm{~kg} / \mathrm{d}$; thus, metabolizable protein clearly was more limiting than energy and it was anticipated that responses to increasing supply of microbial protein with incremental supplements of liquid molasses should be more evident in this study.

A number of the production responses with increasing dietary sugar gave significant linear, quadratic, and cubic effects (Table 4). There was an increase of $2.7 \mathrm{~kg} / \mathrm{d}$ in DMI with the first increment of molasses supplementation, reflecting the intake response that has been observed in dairy cows and that was discussed earlier (Fisher et al., 1999, 2002). Because intake declined with further sugar addition, the response was characterized as both quadratic and cubic. In addition, there were linear improvements $(P \leq 0.09)$ in milk content of protein and SNF, MUN concentration, and in apparent NDF and ADF digestibility. However, most notable in this trial was the large number of quadratic responses $(P<0.01$ to $P=0.10)$ to increasing dietary sugar. In addition to DMI, quadratic effects were observed for yield of milk, protein, and SNF, and milk concentration of protein, SNF, and MUN, apparent digestibility of NDF and ADF, estimated urinary excretion of PD (Table 4), and ruminal ammonia concentration (Table 5). Overall, these responses suggested that sugar supplementation improved performance over the control diet but that production actually declined after the maxima, indicating that sugar was being fed in excess. Morales et al. (1989) observed a differential response to liquid molasses feeding: $4 \%$ molasses DM increased, but 8\% molasses reduced, milk production when added to a diet containing $35 \%$ alfalfa silage. However, both 4 and $8 \%$ molasses DM improved production when supplementing a $65 \%$ alfalfa silage diet. Huhtanen and Hissa (1996) reported depressed weight gain and feed efficiency when about 4 and $8 \%$ molasses DM were added to a grass silage diet fed to growing bulls. Lactose yield, which did not display a significant quadratic response, was lowest at the highest level of molasses feeding. The magnitude of the optima for dietary sugar content from both trials will be discussed in the following section.

Of the 14 cubic effects that were detected $(P \leq 0.07)$ in addition to that for DMI, 11 showed a pattern somewhat related to DMI. Apparent DM and N efficiencies 
and apparent DM and OM digestibilities were highest, and estimated fecal $\mathrm{N}$ and DM output lowest, on control and 6\% liquid molasses (the diets that resulted in lower intakes), with opposite effects observed on 3 and 9\% liquid molasses (the 2 diets giving higher intakes), reflecting the expected inverse relationships between intake and efficiency and intake and digestibility. Excretion of PD would be expected to parallel microbial nucleic acids formation that would be proportional to feed consumption. Urine volume should be related to feed intake and dietary molasses content because of the need, for example, to excrete the potassium in alfalfa silage and molasses. Milk protein, lactose, and SNF concentrations tended to follow intake; levels of milk components other than fat are often influenced by energy consumption (Cadorniga and Satter, 1993). The significant cubic effects noted for apparent digestibility of NDF and ADF probably were an extension of the quadratic responses for these traits. Ruminal branched-chain VFA, which are products of protein degradation as well as substrates for synthesis of leucine, isoleucine, and valine in certain ruminal bacteria (Allison, 1970), were highest on the diet containing 6\% liquid molasses, and gave a cubic response.

Unlike trial 1, several more favorable production responses were observed with sugar supplementation in this study. These may have occurred because the basal diet was lower in $\mathrm{CP}$ and higher in nonstructural carbohydrate, because there was a greater intake response to molasses, and because cows averaged $6 \mathrm{~kg} /$ $\mathrm{d}$ more milk and 40 fewer DIM in this trial. Ruminal ammonia declined, and PD excretion was elevated, indicating that microbial protein supply increased on the diet with 3\% liquid molasses. Assuming an 86\% urinary excretion of purines flowing to the duodenum (Vagnoni et al., 1997) and a microbial CP:purine ratio of $4 \mathrm{~g}$ of $\mathrm{CP} / \mathrm{mmol}$ of total purines (Vagnoni and Broderick, 1997), an increase in PD excretion of $72 \mathrm{mmol} / \mathrm{d}$ would correspond to about $335 \mathrm{~g} / \mathrm{d}$ of additional microbial protein. This would provide $214 \mathrm{~g} / \mathrm{d}$ of metabolizable protein, sufficient to support yield of $144 \mathrm{~g}$ of milk protein or $4.6 \mathrm{~kg} / \mathrm{d}$ of milk with $3.1 \%$ protein. Actual response was $110 \mathrm{~g} / \mathrm{d}$ of milk protein and $1.9 \mathrm{~kg} / \mathrm{d}$ of milk with $3.2 \%$ protein (Table 4 ). Of course, part of the effect on PD excretion likely was driven by the large initial response in feed consumption.

As in trial 1, there were no significant ruminal effects of sugar supplementation except on ammonia concentration (Table 5). However, there were some interesting differences between responses in the 2 trials. Although diets fed in trial 2 were 6 percentage units higher in NFC, mean ruminal $\mathrm{pH}$ and total VFA concentrations also were greater than in trial 1 . Dietary CP had effects on ruminal ammonia (Table 5) that were paralleled by MUN (Table 3 and 4): Mean concentrations were $15.5 \mathrm{mg} / \mathrm{dL}$ of ammonia $\mathrm{N}$ and $14.9 \mathrm{mg} / \mathrm{dL}$ of MUN in trial $1(18 \% \mathrm{CP})$ and $7.6 \mathrm{mg} /$ $\mathrm{dL}$ of ammonia $\mathrm{N}$ and $10.5 \mathrm{mg} / \mathrm{dL}$ of MUN in trial 2 $(15.6 \% \mathrm{CP})$. In a number of studies, we have observed strong correlations between dietary $\mathrm{CP}$ and concentrations of ruminal ammonia and MUN (Broderick and Clayton, 1997). The responses in the current trial also suggested that increased sugar intake improved $\mathrm{N}$ use despite the negative linear response observed for milk $\mathrm{N} / \mathrm{N}$-intake. Levels of MUN dropped to a minimum with the first increment of molasses addition (Table 4) and ruminal ammonia was lowest on 3 and $6 \%$ liquid molasses (Table 5). As discussed earlier, both ruminal ammonia $(P=0.06)$ and MUN $(P=0.04)$ gave quadratic responses to sugar feeding.

\section{Optimal Dietary Sugar}

Significant $(P<0.10)$ quadratic effects of molasses addition were observed for yield of $3.5 \% \mathrm{FCM}$ and fat, milk fat content, and ruminal ammonia in trial 1 , and for DMI, yield of milk, protein, and SNF, milk content of protein, SNF, and MUN, apparent digestibility of $\mathrm{NDF}$ and $\mathrm{ADF}, \mathrm{PD}$ excretion, and ruminal ammonia in trial 2. The quadratic equations obtained from regressing these factors on concentration of total dietary sugar, determined from analysis (using phenol-sulfuric acid assay of Hall et al., 1999; T. K .M. Webster, personal communication, 2003) of TMR composites collected during each trial (Table 2), along with the estimated optima for dietary sugar, are presented in Table 6 . The dietary optima for the significant quadratics in trial 1 ranged only from 4.7 to $5.0 \%$ total sugar with an overall mean of $4.8 \%$. The control TMR without dried molasses contained $2.6 \%$ total sugar, so the optimum represented $2.2 \%$ added sugar as analyzed. Individual optima for the 11 production traits giving significant quadratic responses in trial 2 ranged from 4.9 (SNF yield) to $7.8 \%$ (MUN concentration) with an overall mean of $6.3 \%$ total sugar (corresponding to $3.7 \%$ added sugar). The average optimum from all 15 quadratic equations was 5.9\% total sugar; however, the average was $5.6 \%$ based on the TMR analyses if only one mean was used from each trial.

The optima from trial 2 resolved into 3 groups: Those for yield only (4.9 to $5.6 \%$ total sugar), those related to microbial growth in the rumen (5.6 and 6.0\% total sugar), and those for intake, milk composition, and apparent digestibility (6.8 to $7.8 \%$ total sugar). We reasoned that, because improved milk and component yield would be the most economically advantageous, a more conservative estimate of an overall optimum for dietary sugar would be obtained if only values from 
significant yield responses were considered. This approach gave means of $4.8 \%$ from trial 1 and $5.3 \%$ from trial 2 , an overall optimum of $5.0 \%$ total sugar obtained by adding $2.4 \%$ total sugar as dried or liquid molasses. It is recognized that these estimates were probably influenced by the differing diet compositions and types of yield responses, as well as by the substantial effects on DMI in the 2 trials. However, the overall mean may be considered an initial estimate for optimal dietary sugar for lactating dairy cows. These diets were based on alfalfa silage, corn silage, and HMSC, all fermented feeds with low residual sugar. Although less supplemental sugar might be required in diets with higher backgrounds, the value of $5 \%$ total sugar DM may still be appropriate. Hall (2002) cited data that suggested feeding 5\% total sugar in the diet.

Carbohydrate source will influence the nature of the ruminal response. Chamberlain et al. (1993) reported that supplementing grass silage diets with small amounts of nonstructural carbohydrates was effective in stimulating urinary excretion of PD in sheep, in the order of sucrose $>$ lactose $>$ fructose $>$ xylose $>$ wheat starch. Later Scottish work indicated that ruminal infusions of sucrose (Kim et al., 1999b) and maltodextrin (Kim et al., 1999a), in supplement of grass silage diets fed to dairy cattle, stimulated microbial protein synthesis in the rumen. Trevaskis et al. (2001) reported that ruminal sucrose infusion was more effective for stimulating microbial protein formation (as indicated by urinary excretion of PD) when it was synchronized with the ammonia peak occurring 1 to $2 \mathrm{~h}$ after feeding. Korean research (Kim et al., 2000) also showed a positive effect of sucrose infusion into the rumen but no advantage of synchrony with ruminal ammonia. The DM in cane molasses contains about $70 \%$ total sugars-of which $46 \%$ is sucrose and $24 \%$ is fructose plus glucose-and about $10 \%$ other fermentable material (Dave Caldwell, personal communication, 2003). Analyses of the TMR fed in trial 2 suggested that the DM in liquid molasses contained $85 \%$ rather than $70 \%$ total sugars (using sucrose as standard; T. K. M. Webster, personal communication, 2003). Assay effects and other factors may explain the discrepancy. Had glucose or fructose been used as standard rather than sucrose, and assuming the same response per monomer, then sugar DM would have been determined at $11 \%$ higher concentrations in the TMR analyses. Other possible factors include differences in monomer response in the sugar assay and mixing errors in TMR preparation. Although molasses will serve largely as a sucrose source, $40 \%$ of its energy comes from other fermentable substrates and there is some dilution by ash. The DM of HMSC fed in both trials averaged $1.5 \%$ ash; this DM was replaced in trial 2 by DM from liquid molasses that contained $15 \%$ sulfated ash, about one-third of which was potassium (Dave Caldwell, personal communication, 2003). Because large hexose polymers such as starch have lost the weight of 1 water of hydration per sugar unit, they are more energy dense than mono- and di-hexoses, which contain only 90 and $95 \%$ as much usable energy, respectively. Thus, dietary energy was diluted when molasses replaced HMSC. This may explain some of the decline in production observed at the highest levels of dietary molasses despite the positive effects of sucrose and other sugars on ruminal microbial growth.

\section{SUMMARY}

Adding sugar as dried molasses to a diet formulated from alfalfa and corn silages plus HMSC, containing (on a DM basis) $18 \% \mathrm{CP}, 42 \% \mathrm{NFC}$, and $2.6 \%$ total sugar, increased DMI, yield of FCM and fat, apparent $\mathrm{DM}$ and fiber digestibility, and reduced ruminal ammonia and urinary $\mathrm{N}$ excretion. Because FCM and protein yield did not increase along with DMI, there were linear decreases in FCM/DMI and milk N/N-intake. Adding sugar as liquid molasses to a diet formulated from alfalfa and corn silages plus HMSC, containing (on a DM basis) $15.6 \% \mathrm{CP}, 42 \% \mathrm{NFC}$, and $2.6 \%$ total sugar, increased DMI, yield of milk, protein, and SNF, apparent digestibility, urinary excretion of PD, and reduced ruminal ammonia. Over both trials, there were significant quadratic responses for yield of FCM, fat, and ruminal ammonia, and for yield of milk, protein, and SNF, NDF and ADF digestibility, MUN, urinary PD, and ruminal ammonia. An estimate of the overall optimum for total dietary sugar based on yield of milk and milk components was about $5.0 \%$ total sugar, obtained by adding $2.4 \%$ total sugar as dried or liquid molasses to basal diets containing $2.6 \%$ total sugar. Overfeeding of sugar appeared to reduce performance.

\section{ACKNOWLEDGMENTS}

The authors thank Rick Walgenbach and the farm crew for harvesting and storing the feedstuffs used in these trials; Len Strozinski, Jill Davidson, and the barn crew for feeding and animal care at the US Dairy Forage Center Research Farm (Prairie du Sac, WI); Mary Becker and Adam Ford for assisting with sampling and laboratory analyses; Tammy K. Miller Webster and Mary Beth Hall for total sugar analyses on TMR and molasses supplements; Peter Crump for assisting with statistical analyses; and Dave Caldwell (Westway Trading Co.) for providing the liquid molasses and dispensing equipment used in trial 2. 


\section{REFERENCES}

Allison, M. J. 1970. Nitrogen metabolism of ruminal micro-organisms. Pages 456-463 in Physiology of Digestion and Metabolism in the Ruminant. A. T. Phillipson, ed. Oriel Press, Newcastle upon Tyne, United Kingdom.

Association of Official Analytical Chemists. 1980. Official Methods of Analysis. 13th ed. AOAC, Washington, DC.

Association of Official Analytical Chemists. 1997. Official Methods of Analysis. 16th ed. AOAC, Washington, DC.

Bal, M. A., R. D. Shaver, A. G. Jirovec, K. J. Shinners, and J. G. Coors. 2000. Crop processing and chop length of corn silage: Effects on intake, digestion, and milk production by dairy cows. J. Dairy Sci. 83:1264-1273.

Broderick, G. A., and M. K. Clayton. 1997. A statistical evaluation of animal and nutritional factors influencing concentrations of milk urea nitrogen. J. Dairy Sci. 80:2964-2971.

Broderick, G. A., R. G. Koegel, M. J. C. Mauries, E. Schneeberger, and T. J. Kraus. 1999. Effect of feeding macerated alfalfa silage on nutrient digestibility and milk yield in lactating dairy cows. J. Dairy Sci. 82:2472-2485.

Broderick, G. A., N. D. Luchini, W. J. Smith, S. Reynal, G. A. Varga, and V. A. Ishler. 2000. Effect of replacing dietary starch with sucrose on milk production in lactating dairy cows. J. Dairy Sci. 83(Suppl. 1):248.(Abstr.)

Broderick, G. A., R. P. Walgenbach, and S. Maignan. 2001. Production of lactating dairy cows fed alfalfa or red clover silage at equal dry matter or crude protein contents in the diet. J. Dairy Sci. 84:1728-1737.

Cadorniga, C. P., and L. D. Satter. 1993. Protein versus energy supplementation of high alfalfa silage diets for early lactation cows. J. Dairy Sci. 76:1972-1980.

Chamberlain, D. G., S. Robertson, and J. J. Choung. 1993. Sugars versus starch as supplements to grass silage: Effects of ruminal fermentation and the supply of microbial protein to the small intestine, estimated from the urinary excretion of purine derivatives, in sheep. J. Sci. Food Agric. 63:189-194

Cochran, R. C., D. C. Adams, J. D. Wallace, and M. L. Galyean. 1986. Predicting digestibility of different diets with internal markers: Evaluation of four potential markers. J. Anim. Sci. 63:1476-1487.

Dijkstra, J., H. Boer, J. Van Bruchem, M. Bruining, and S. Tamminga. 1993. Absorption of volatile fatty acids from the rumen of lactating dairy cows as influenced by volatile fatty acid concentration, $\mathrm{pH}$ and rumen liquid volume. Br. J. Nutr. 69:385-396.

Ekinci, C. 1995. Effect of processing of high moisture corn on production and rumen parameters of dairy cows. M.S. Thesis, Univ. Wisconsin, Madison.

Fisher, D. S., H. F. Mayland, and J. C. Burns. 1999. Variation in ruminants' preference for tall fescue hays cut either at sundown or at sunup. J. Anim. Sci. 77:762-768.

Fisher, D. S., H. F. Mayland, and J. C. Burns. 2002. Variation in ruminant preference for alfalfa hays cut at sunup and sundown. Crop Sci. 42:231-237.

Hall, M. B. 2002. Working with sugars (and molasses). Pages 146158 in Proc. 13th Annu. Florida Ruminant Nutrition Symp., Gainesville, FL.

Hall, M. B., and C. Herejk. 2001. Differences in yields of microbial crude protein from in vitro fermentation of carbohydrates. J. Dairy Sci. 84:2486-2493.

Hall, M. B., W. H. Hoover, J. P. Jennings, and T. K. M. Webster. 1999. A method for partitioning neutral detergent-soluble carbohydrates. J. Sci. Food Agric. 79:2079-2086.

Hintz, R. W., D. R. Mertens, and K. A. Albrecht. 1995. Effects of sodium sulfite on recovery and composition of detergent fiber and lignin. J. AOAC 78:16-22.

Huhtanen, P. 1987. The effect of dietary inclusion of barley, unmolassed sugar beet pulp and molasses on milk production, digestibility and digesta passage in dairy cows given silage based diet. J. Agric. Sci. (Camb.) 59:101-120.

Huhtanen, P. 1988. The effects of barley, unmolassed sugar-beet pulp and molasses supplements on organic matter, nitrogen and fiber digestion in the rumen of cattle given a silage diet. Anim. Feed Sci. Technol. 20:259-278.

Huhtanen, P., and K. Hissa. 1996. The influence of molasses and yeast culture on the performance of growing bulls on grass silagebased diet. J. Anim. Feed Sci. 5:201-214.

Huhtanen, P., K. Kaustell, and S. Jaakkola. 1994. The use of internal markers to predict total digestibility and duodenal flow of nutrients in cattle given six different diets. Anim. Feed Sci. Technol. 48:211-227.

Hussein, H. S., M. R. Cameron, G. C. Fahey, Jr., N. R. Merchen, and J. H. Clark. 1995. Influence of altering ruminal degradation of soybean meal protein on in situ ruminal fiber disappearance of forages and fibrous byproducts. J. Anim. Sci. 73:2428-2437.

Khalili, H., and P. Huhtanen. 1991. Sucrose supplements in cattle given grass silage-based diet: 1 . Digestion of organic matter and nitrogen. Anim. Feed Sci. Technol. 33:247-262.

Kim, K. H., J. J. Choung, and D. G. Chamberlain. 1999a. Effects of varying the degree of synchrony of energy and nitrogen release in the rumen on the synthesis of microbial protein in lactating dairy cows consuming a diet of grass silage and a cereal-based concentrate. J. Sci. Food Agric. 79:1441-1447.

Kim, K. H., S. S. Lee, B. T. Jeon, and C. W. Kang. 2000. Effects of the pattern of energy supply on the efficiency of nitrogen utilization for microbial protein synthesis in the non-lactating cows consuming grass silage. Asian-Australas. J. Anim. Sci. 13:962-966.

Kim, K. H., Y. G. Oh, J. J. Choung, and D. G. Chamberlain. 1999b. Effects of varying degrees of synchrony of energy and nitrogen release in the rumen on the synthesis of microbial protein in cattle consuming grass silage. J. Sci. Food Agric. 79:833-838.

Leng, R. A. 1970. Formation and production of volatile fatty acids in the rumen. Page 406 in Physiology of Digestion and Metabolism in the Ruminant. A. T. Phillipson, ed. Oriel Press, Newcastle upon Tyne, United Kingdom.

McDonald, P., A. R. Henderson, and S. J. E. Heron. 1991. The Biochemistry of Silage. J. Wiley and Sons, New York, NY.

Morales, J. L., H. H. Van Horn, and J. E. Moore. 1989. Dietary interaction of cane molasses with source of roughage: Intake and lactation effects. J. Dairy Sci. 72:2331-2338.

Muck, R. E. 1987. Dry matter level effects on alfalfa silage quality. 1. Nitrogen transformations. Trans. ASAE 30:7-14.

Murphy, J. J. 1999. The effects of increasing the proportion of molasses in the diet of milking dairy cows on milk production and composition. Anim. Feed Sci. Technol. 78:189-198.

Murphy, M. R. 1982. Analyzing and presenting pH data. J. Dairy Sci. 65:161-163.

Murphy, M. R., A. W. P. Geijsel, E. C. Hall, and R. D. Shanks. 1997. Dietary variety via sweetening and voluntary feed intake of lactating dairy cows. J. Dairy Sci. 80:894-897.

Nagel, S. A., and G. A. Broderick. 1992. Effect of formic acid or formaldehyde treatment of alfalfa silage on nutrient utilization by dairy cows. J. Dairy Sci. 75:140-154.

National Research Council. 1996. Nutrient Requirements of Beef Cattle. 7th rev. ed. Natl. Acad. Sci., Washington, DC.

National Research Council. 2001. Nutrient Requirements of Dairy Cattle. 7th rev. ed. Natl. Acad. Sci., Washington, DC.

Oser, B. L. 1965. Hawk's Physiological Chemistry. 14th ed. McGrawHill, New York, NY.

Owens, V. N., K. A. Albrecht, R. E. Muck, and S. H. Duke. 1999. Protein degradation and fermentation characteristics of red clover and alfalfa silage harvested with varying levels of total nonstructural carbohydrates. Crop Sci. 39:1873-1880.

Roth, M. 1971. Fluorescence reaction of amino acids. Anal. Chem. 43:880-882.

Sannes, R. A., M. A. Messman, and D. B. Vagnoni. 2002. Form of rumen-degradable carbohydrate and nitrogen on microbial protein synthesis and protein efficiency of dairy cows. J. Dairy Sci. 85:900-908.

SAS. 1999. SAS/STAT User's Guide (Release 8.1), SAS Inst., Inc. Cary, NC. 
Shahani, K. M., and H. H. Sommer. 1951. The protein and nonprotein nitrogen fractions in milk. I. Methods of analysis. J. Dairy Sci. 34:1003-1009.

Sklan, D., R. Ashkenazi, A. Braun, A. Devorn, and K. Tabori. 1992. Fatty acids, calcium soaps of fatty acids, and cottonseeds fed to high yielding cows. J. Dairy Sci. 75:2463-2472.

Stokes, S. R., W. H. Hoover, T. K. Miller, and R. P. Manski. 1991. Impact of carbohydrate and protein levels on bacterial metabolism in continuous culture. J. Dairy Sci. 74:860-870.

Sutton, J. D., R. H. Phipps, S. B. Cammell, and D. J. Humphries. 2001. Attempts to improve the utilization of urea-treated wholecrop wheat by lactating dairy cows. Anim. Sci. 73:137-147.

Trevaskis, L. M., W. J. Fulkerson, and J. Gooden. 2001. Provision of certain carbohydrate-based supplements to pasture-fed sheep, as well as time of harvesting of the pasture, influences $\mathrm{pH}$, ammonia concentration and microbial protein synthesis in the rumen. Aust. J. Exp. Agric. 41:21-27.
Vagnoni, D. B., and G. A. Broderick. 1997. Effects of supplementation of energy or ruminally undegraded protein to lactating cows fed alfalfa hay or silage. J. Dairy Sci. 80:1703-1712.

Vagnoni, D. B., G. A. Broderick, M. K. Clayton, and R. D. Hatfield. 1997. Excretion of purine derivatives by Holstein cows abomasally infused with incremental amounts of purines. J. Dairy Sci. 80:1695-1702.

Valadares, R. F. D., G. A. Broderick, S. C. Valadares Filho, and M. K. Clayton. 1999. Effect of replacing alfalfa silage with high moisture corn on ruminal protein synthesis estimated from excretion of total purine derivatives. J. Dairy Sci. 82:2686-2696.

Van Soest, P. J., J. B. Robertson, and B. A. Lewis. 1991. Methods for dietary fiber, neutral detergent fiber and nonstarch polysaccharides in relation to animal nutrition. J. Dairy Sci. 74:3583-3597.

Vogels, G. D., and C. van der Grift. 1970. Differential analyses of glyoxylate derivatives. Anal. Biochem. 33:143-157. 